\title{
Characteristics of the
} syneruptive-spouted type lahar generated by the September 2014 eruption of Mount Ontake, Japan

\author{
Hisashi Sasaki , Tatsuro Chiba, Hiroshi Kishimoto and Shino Naruke
}

\begin{abstract}
Mount Ontake erupted at 11:52 am on September 27, 2014, which generated pyroclastic density currents, ballistic projectiles, ash falls, and a small-scale lahar that spouted directly from craters formed by the eruption. Because this lahar may have been generated by water released from within these craters, we refer to this lahar as a "syneruptivespouted type lahar" in this study. The lahar of the 2014 eruption was small relative to the other syneruptive type lahars reported in the past that were snowmelt type or crater lake breakout type lahars. Nevertheless, in the 2014 event, the syneruptive-spouted type lahar extended approximately $5 \mathrm{~km}$ downstream from the Jigokudani crater via the Akagawa River, with an estimated total volume of $\sim 1.2 \times 10^{5} \mathrm{~m}^{3}$. We have reviewed other representative syneruptivespouted type lahars that have been reported in Japan. The syneruptive-spouted type lahar attributed to the September 2014 eruption had the longest runout distance and largest volume of all cases studied. The mineral assemblage identified from samples of the lahar deposits is similar to that of ash-fall deposits from the same eruption. Previous workers deduced that the ash was derived mainly from shallow depths (within $2 \mathrm{~km}$ of the surface). The syneruptivespouted type lahar deposits are therefore also considered to have originated from shallow depths. A syneruptivespouted type lahar is a small-scale phenomenon that causes little direct damage to infrastructure, but has long-term influence on water quality. Increases in turbidity and decreases in $\mathrm{pH}$ are expected to occur in the Mount Ontake area downstream of Nigorisawa after heavy rainfall events in the future. Therefore, the potential indirect (but long term) damage of syneruptive-spouted type lahars should be considered for hazard mapping and planning volcanic disaster prevention measures.
\end{abstract}

Keywords: Phreatic eruption, Syneruptive-spouted type lahar, Muddy water, Water quality, Ontake volcano

\section{Introduction}

Mount Ontake $(3067 \mathrm{~m})$ is an active stratovolcano located at the prefectural border of Nagano and Gifu in central Japan (Fig. 1). Mount Ontake erupted at 11:52 am on September 27, 2014, which generated pyroclastic density currents, ballistic projectiles, ash falls, and a small-scale lahar that spouted directly from craters formed by the eruption (Nakano et al. 2014; Oikawa et al. 2014; Kaneko et al. 2016). Because this lahar may

\footnotetext{
*Correspondence: hss.sasaki@ajiko.co.jp

Asia Air Survey Co. Ltd., 1-2-2, Manpukuji, Asao-ku, Kawasaki 215-0004, Japan
}

(c) 2016 The Author(s). This article is distributed under the terms of the Creative Commons Attribution 4.0 International License (http://creativecommons.org/licenses/by/4.0/), which permits unrestricted use, distribution, and reproduction in any medium, provided you give appropriate credit to the original author(s) and the source, provide a link to the Creative Commons license, and indicate if changes were made.

have been caused by water released from within these craters, we refer to this lahar as a "syneruptive-spouted type lahar." Similar lahars have been documented from the Mount Usu eruption of March 2000 (Mizugaki et al. 2001; Hirose et al. 2007), the Meakandake eruption of March 2006 (Sasaki et al. 2006), and the Hakone eruption of June 2015 (Mannen et al. 2015).

For this study, we have assessed the distribution of syneruptive-spouted type lahar deposits using oblique aerial photographs, analyzed their morphology, evaluated the mechanisms of their generation, investigated their indirect impacts, and compared them with other examples of this type of lahar documented in Japan.

\section{Springer Open}




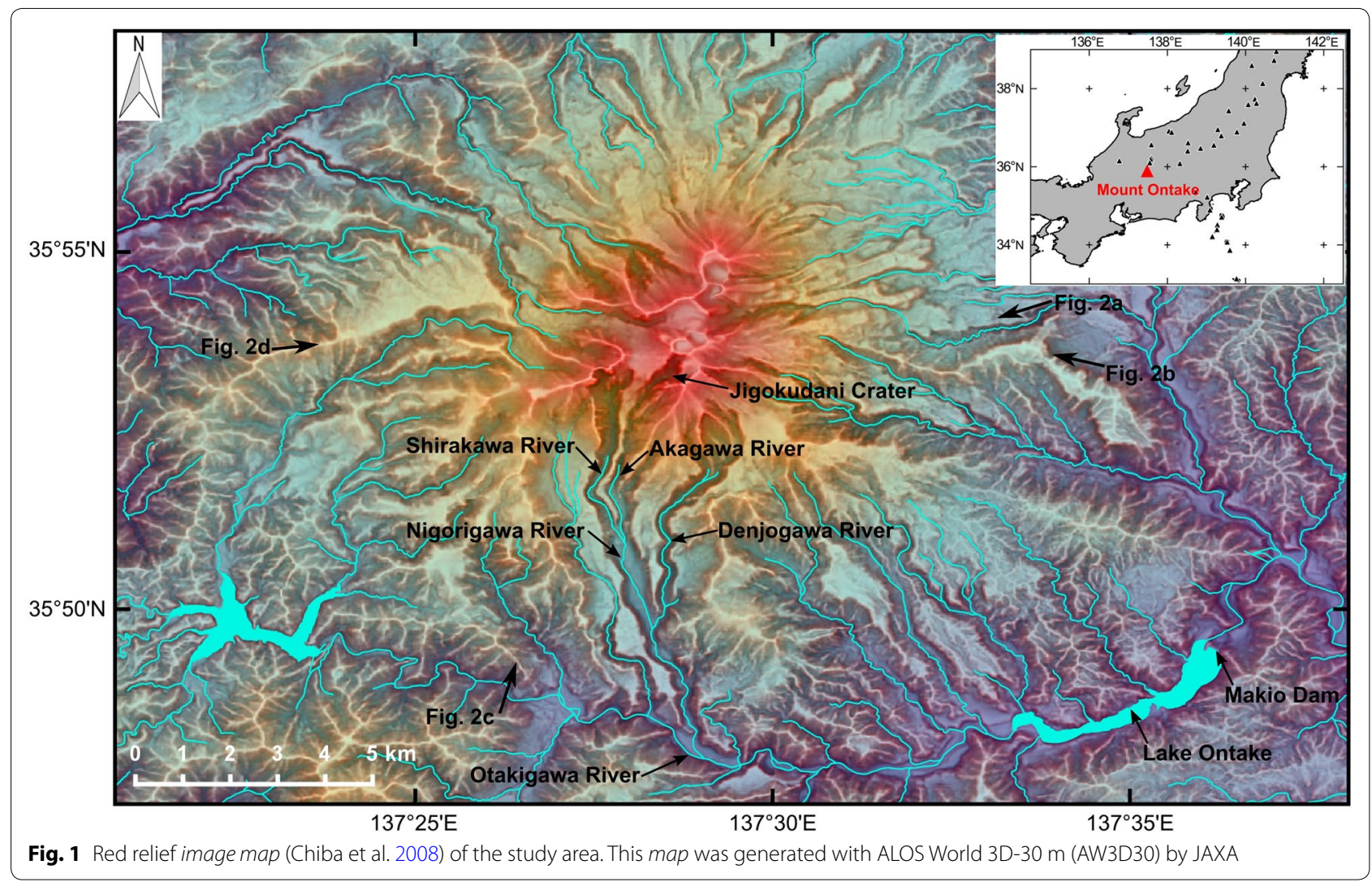

\section{Interpretation of oblique aerial photographs}

Workers affiliated with Asia Air Survey Co., Ltd., captured oblique aerial photographs of the outside of the prohibited area on September 28, 2014, the day after the September 2014 eruption (Figs. 2, 3). The area surrounding the summit of Mount Ontake was covered by gray-colored ash fall (Fig. 2a), which was most prominent northeast of the crater and turned vegetation in the affected area gray (Fig. 2b). The pyroclastic density current deposits were distributed northwest and south of the crater, and their coverage is also shown by a gray color in the oblique aerial photographs (Fig. 2c, d). Maeno et al. (2016) estimated a total volume of ash-fall and pyroclastic density current deposits of $0.7-1.3 \times 10^{6} \mathrm{~m}^{3}$.

The syneruptive-spouted type lahar flowed into the Nigorisawa River on the south side of the Jigokudani crater (Fig. 3a). The Jigokudani crater could not be seen in the photographs because of smoke, but a gutter of water from a crater wall could be identified (Fig. 3b). Photographs showing that the lahar overflowed from the Jigokudani crater have been presented by Kaneko et al. (2016). The western crater is a new crater that formed during the 2014 eruption. Flowing water was observed around this new crater and the tongue-shaped lahar, and its presence was confirmed at the bottom of the new crater (Fig. 3c). The ejected volume from this part of the eruption was very small and therefore is not essential to the following discussion.

Although the pyroclastic density current deposits were partially eroded by the flow of the Shirakawa River, no large-scale reworking of these deposits has been recognized (Fig. 3d). In the Akagawa River, downstream of the Jigokudani crater, gray lahar deposits were observed on the valley floor (Fig. 3d, e). The lahar overflowed at the confluence of the Akagawa and Shirakawa Rivers. Muddy water mainly flowed downstream from site $\mathrm{C}$ (Fig. 3e, f).

\section{Distribution of the syneruptive-spouted type lahar and muddy water}

We have produced a distribution map of the syneruptivespouted type lahar using oblique aerial photographs and red relief image maps (Chiba et al. 2008) (Fig. 4a) and differentiated the lahar from muddy water (Fig. 4b). The syneruptive-spouted type lahar travelled approximately $5 \mathrm{~km}$ downstream from the Jigokudani crater via the Akagawa River. Muddy water flowed downstream from site $C$ and down the Otakigawa River until it arrived at Lake Ontake. The distance from the Jigokudani crater to the junction of the Nigorigawa and Otakigawa Rivers (site E) is $\sim 11.5 \mathrm{~km}$. The syneruptive-spouted type 

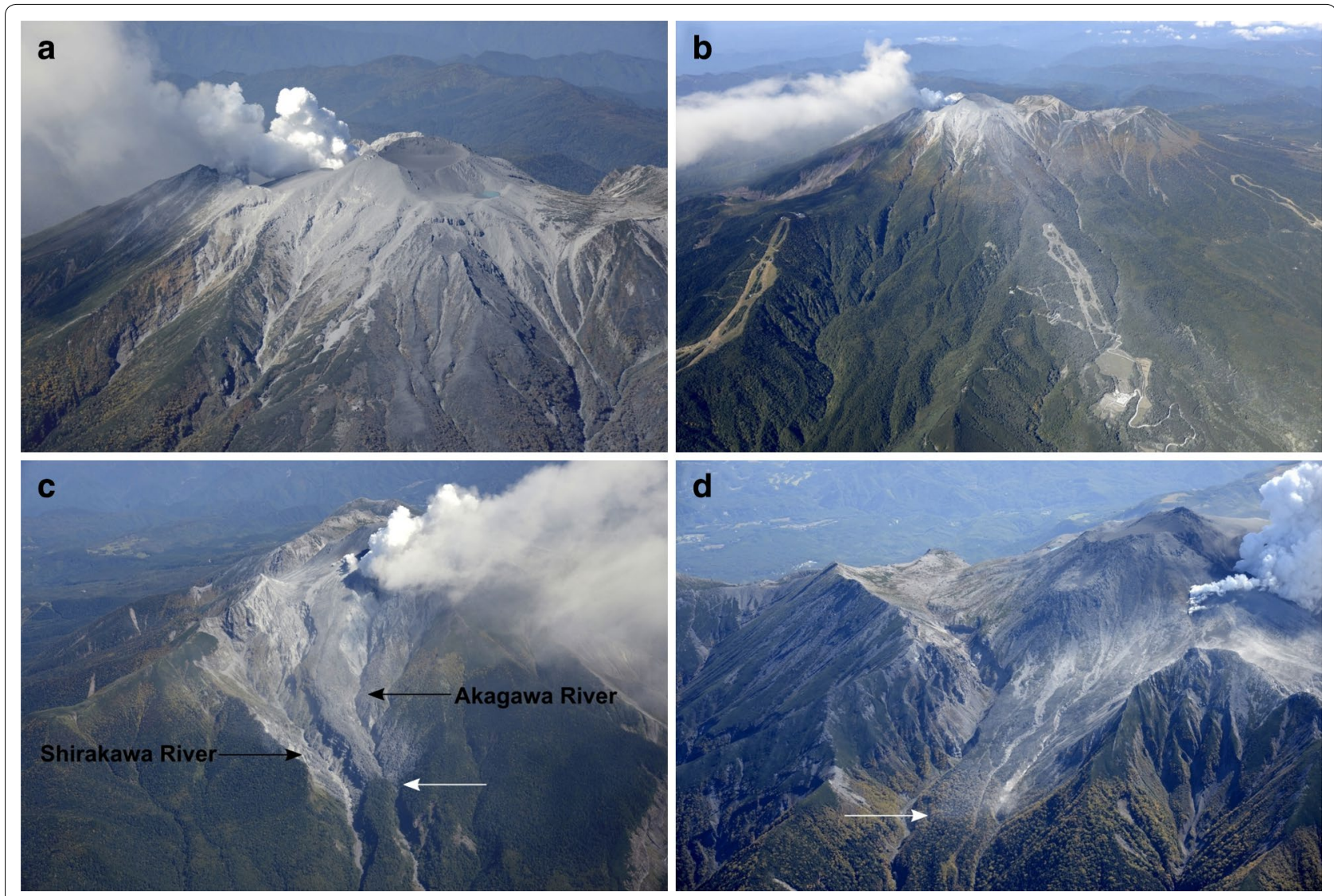

Fig. 2 Oblique aerial photographs of the pyroclastic fall and pyroclastic density current deposits taken after the September 2014 eruption. a Area around the summit, photographed from the east at 09:49 am, September 28, 2014. b The hillside, photographed from the east at 09:48 am, September 28, 2014. The ash-fall deposit spread toward the northeast. c Jigokudani crater, photographed from the south at 09:56 am, September 28, 2014. The area covered by pyroclastic density current deposits is gray in color. The distal end of the pyroclastic density current travelled $\sim 2 \mathrm{~km}$ outward from the crater (white arrow). d A new crater, photographed from the northeast at 09:59 am, September 28, 2014. The area covered by pyroclastic density current deposits is light gray in color. The distal end of the pyroclastic density current travelled $\sim 1.5 \mathrm{~km}$ outward from the crater (white arrow)

lahar deposits in the Akagawa River covered an area of $\sim 1.2 \times 10^{5} \mathrm{~m}^{2}$ with a mean thickness of $\sim 1 \mathrm{~m}$, for a total volume of $\sim 1.2 \times 10^{5} \mathrm{~m}^{3}$.

\section{Characteristics of the syneruptive-spouted type lahar deposits \\ Occurrence of syneruptive-spouted type lahar deposits}

We conducted fieldwork 10 months after the September 2014 eruption at four localities (sites A, B, C, and D), which are shown in Fig. 4. A check dam at site B was full of syneruptive-spouted type lahar deposits (Fig. 5a). A member of the Forestry Agency photographed site B on October 2, 2014. The syneruptive-spouted type lahar deposited material on the wing of the check dam, and desiccation cracks subsequently developed on the deposit's surface (Fig. 5b). Because the front of the deposit had a lobate form, it is possible that the material was cohesive. Figure $5 \mathrm{c}$ shows the main stream of the Akagawa River near site B, which was photographed by a member of the Forestry Agency at 11:30 am on October 2,2014 . The lahar flowed through site B 5 days after the eruption. The syneruptive-spouted type lahar penetrated into a forested area, although it did not overturn any trees (Fig. 5d); nonetheless, a syneruptive-spouted type lahar deposit overlying a fallen tree was observed in the forest (Fig. 5e). At site $\mathrm{D}$, a gray syneruptive-spouted type lahar deposit was covered in dark brown debris of a debris flow deposit (Fig. 5f), although the syneruptive-spouted type lahar had not arrived at the site by September 28, 2014, when the photograph was taken (Fig. 3f). According to Hayashi et al. (2015), the syneruptive-spouted type lahar deposit arrived at this location on October 5, 2014, caused by typhoon rains; therefore, these lahar deposits may have been the result of post-eruption sediment reworking of the syneruptive-spouted type lahar deposits. Reticular sulfur-bearing veins developed in the lahar deposits (Fig. 5h), which were also filled with coarse sand from the debris flow. 

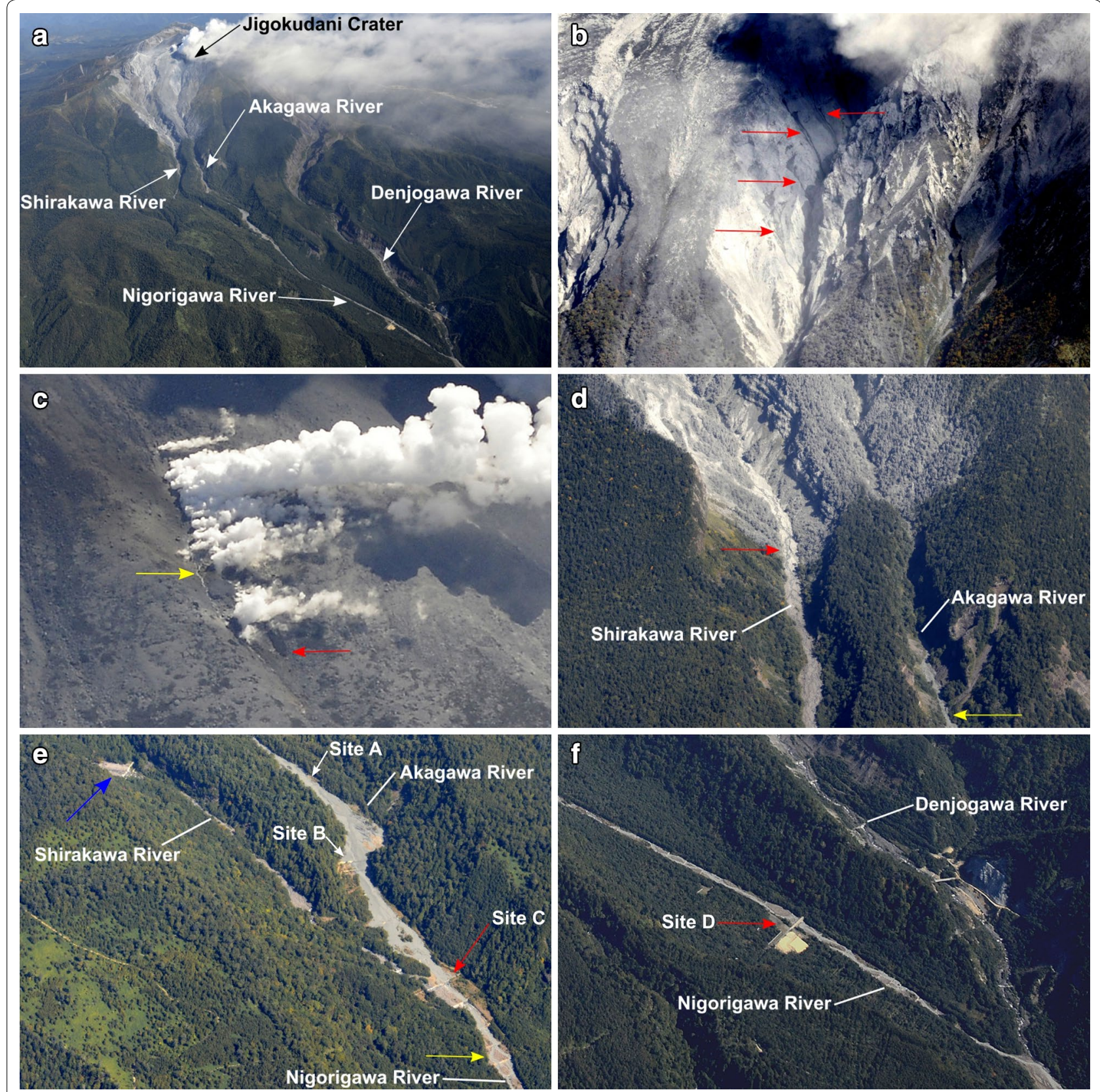

Fig. 3 Oblique aerial photographs of the crater and lahar deposits taken after the September 2014 eruption. $\mathbf{a}$ View of the entire area of the Nigorisawa River through which the syneruptive-spouted type lahar flowed. b One wall of the Jigokudani crater. The red arrows indicate a gutter of water. c The new crater, which formed on the western flank of Mount Ontake. The yellow arrow indicates hot water that overflowed from the crater. The red arrow indicates the tongue-shaped lahar deposit. $\mathbf{d}$ Deposit from the pyroclastic density current that flowed down the south side of the volcano. Running water eroded deposits in the vicinity of the Shirakawa River (red arrow), although the running water was clear. In the Akagawa River, a syneruptive-spouted type lahar was deposited at the bottom of the gorge. e View of the confluence of the Akagawa and Shirakawa Rivers. The syneruptive-spouted type lahar overflowed to the location indicated by the red arrow (site C). Muddy water flowed downstream (yellow arrow). Reworked deposits of the pyroclastic density current were not present at a check dam (blue arrow) of the Shirakawa River. $\mathbf{f}$ View of the confluence of the Nigorigawa and Denjogawa Rivers. The red arrow indicates site D. The syneruptive-spouted type lahar had not arrived at site D by the time this photograph was captured, although a lahar did arrive at this location later because of heavy rain

\section{Grain size of syneruptive-spouted type lahar deposits}

We analyzed the grain-size distributions of the syneruptive-spouted type lahar and debris flow deposits at sites
A and D (Fig. 6). Grain-size distribution analysis was carried out using a test method for particle size distribution in soils (JIS A 1204: 2009). The debris flow deposit sample 

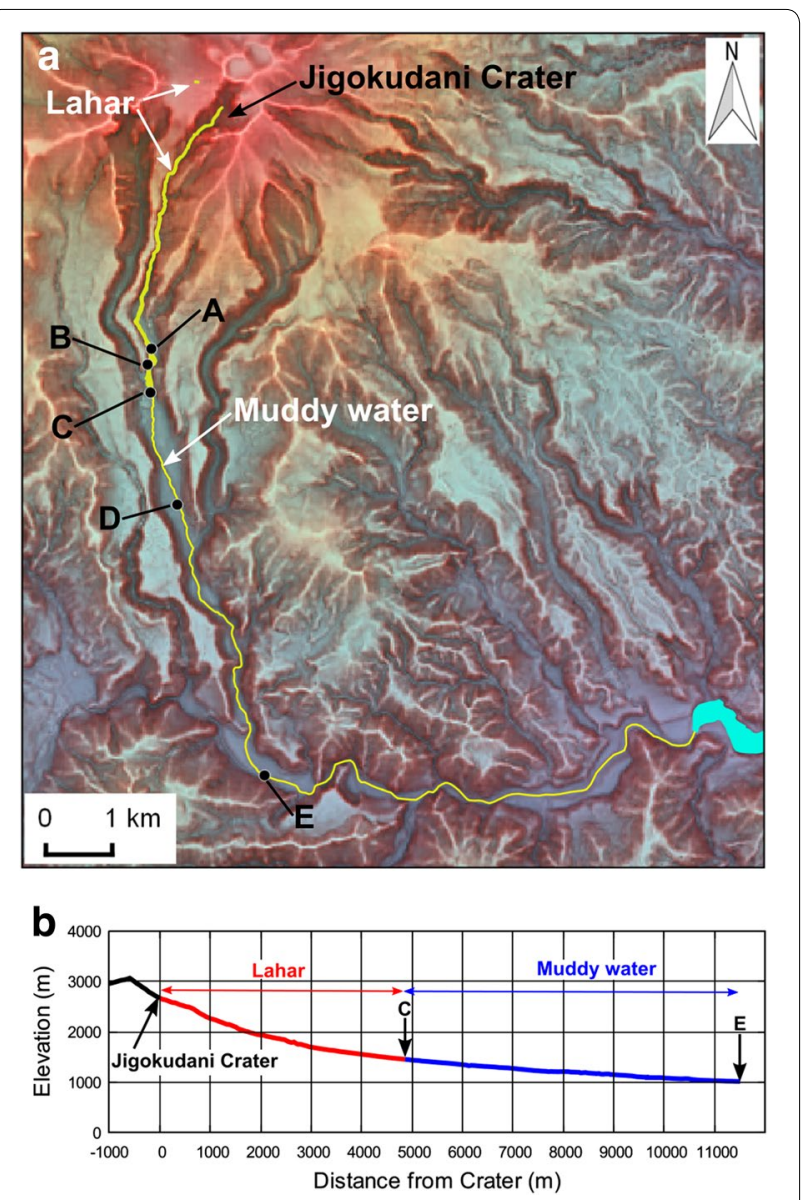

Fig. 4 Distribution of the syneruptive-spouted type lahar and muddy water. The surveyed localities (sites A, B, C, D, and E) are shown. a Distribution of the syneruptive-spouted type lahar and muddy water based on oblique aerial photograph interpretation. b Longitudinal profile from the peak of Mount Ontake to the confluence of the Nigorigawa and Otakigawa Rivers (site E). This map was generated with AW3D30 by JAXA

was predominantly composed of sand-sized particles, whereas the syneruptive-spouted type lahar samples were composed predominantly of silt-sized particles. The syneruptive-spouted type lahar deposits upstream were coarser than those downstream. This pattern resembled that of the 2006 eruption of Meakandake (Hirose et al. 2007).

\section{Matrix components in syneruptive-spouted type lahar deposits}

We collected samples of lahar deposits from sites A and D. Although the lahar deposit at site D was likely affected by rainfall, it was determined that it had the essential lithological characteristics of a syneruptive-spouted type lahar. Rainfall-triggered type lahar deposits contain mainly brown and orange, altered, and spherical lithic fragments and rarely contain white lithic fragments (Fig. 7a). However, the syneruptive-spouted type lahar deposits contained many white and angular lithic fragments (Fig. 7b). Juvenile fragments were not found in the syneruptive-spouted type lahar deposits. Pyrite only occurs in the syneruptive-spouted type lahar deposits (Fig. 7c).

Minerals were identified using X-ray diffraction (XRD). We analyzed a sample of an ash-fall deposit from the same eruption to compare it with samples of the syneruptive-spouted type lahar deposits. XRD analysis was carried out using an XRD-6000 device (Shimadzu Corporation) with a $\mathrm{Cu}$ tube analytical setup and operating conditions of $30 \mathrm{kV}$. A bulk sample was dried and crushed to particles of $\leq 10 \mu \mathrm{m}$ in diameter, and the powdered samples were placed in aluminum sample holders and analyzed. Sample fractions of $<2 \mu \mathrm{m}$ in diameter were extracted via elutriation for analysis. We prepared an oriented sample and an ethylene glycol-treated sample for the identification of smectite.

The resulting XRD charts are shown in Fig. 8, and the identified minerals are listed in Table 1 . The assemblage of hydrothermal minerals identified in all samples comprised quartz, plagioclase, cristobalite, alunite, gypsum, kaolinite, smectite, and pyrite. This mineral assemblage is similar to that of the ash-fall deposits from the 2014 eruption (Minami et al. 2016).

\section{Indirect influence on downstream conditions}

The flow rate of the syneruptive-spouted type lahar was monitored by the Ministry of Land, Infrastructure, Transport and Tourism (2015) at the point where the flow entered the Makio Dam at Lake Ontake. Inflow and outflow fluxes recorded at this location before and after the 2014 eruption are given in Fig. 9. Rainfall on September 25,2014 , i.e., 2 days before the eruption, caused a temporary increase in inflow into the Makio Dam. Although there was variation with discharge, inflow did not increase significantly after the eruption; therefore, inflow from the lahar is interpreted to have been insignificant.

The water quality in the rivers in the Mount Ontake area was monitored after the 2014 eruption by the Japan Water Agency, the Ministry of Land, Infrastructure, Transport and Tourism, the Nagano and Gifu prefectural governments (Fig. 10). We analyzed water quality data at three localities (W1, W2, and W3). At W1, through which the muddy water of the lahar flowed, very high turbidity was recorded following the eruption, although this turbidity gradually decreased. On the downstream side (W2) of the valley, where the pyroclastic density current deposited material, turbidity temporarily increased after the eruption, but decreased immediately afterward. Turbidity downstream (W3) of the area affected by ash 


(See figure on previous page.)

Fig. 5 Photographs of the deposits in the Akagawa and Nigorisawa Rivers. a A check dam at site A. Syneruptive-spouted type lahars deposits filled the wing of the check dam. b Syneruptive-spouted type lahar deposits on the wing of the check dam at site B, photographed by a member the Forestry Agency on October 2, 2014. The front of the deposit had a lobate form, and desiccation cracks had developed on its surface. c The main stream of the Akagawa River near site B, photographed by a member of the Forestry Agency at 11:30 am, October 2, 2014. The lahar flowing through this location at this time, as indicated by a spray of mud in the lower right corner of the photograph. $\mathbf{d}$ Deposit of a syneruptive-spouted type lahar that flowed into a forested area. e The syneruptive-spouted type lahar deposit over a fallen tree. $\mathbf{f}$ A view of the entirety of site D. The gray syneruptive-spouted type lahar deposit was covered by a dark brown debris flow deposit. $\mathbf{f}$ The thickness of the syneruptive-spouted type lahar deposit is approximately $30 \mathrm{~cm}$, and it contains rounded boulders. h Reticular sulfur-bearing veins that developed in the lahar deposits

fall was generally low, but rose during periods of rainfall. The $\mathrm{pH}$ at $\mathrm{W} 1$ decreased to $\sim 4$ after the eruption and continued to decrease during every subsequent rainfall event (Fig. 10). In contrast, the $\mathrm{pH}$ at W2 and W3 decreased shortly after the eruption, but stabilized at $\sim 7$ in the period afterward (Fig. 10).

\section{Discussion and conclusions}

Lahars that occur after volcanic eruptions are often caused by melting snow or heavy rain (Vallance and Iverson 2015); however, neither snow nor a crater lake was documented near to the summit of Mount Ontake prior to the September 2014 eruption, although the groundwater level may have been particularly high because of heavy rain in the 2 days that preceded the eruption. Both a lahar and hot water were reportedly expelled from the Jigokudani cinder cone and the new western crater that developed during the eruption (Kaneko et al. 2016); therefore, we suggest that the lahars directly overflowed from the crater and that one reached as far as $5 \mathrm{~km}$ downstream. Therefore, we term the particular type of lahar investigated for this study a "syneruptivespouted type lahar." The syneruptive-spouted type lahar is thought to be a form of primary (syneruptive) lahar (Vallance and Iverson 2015). The syneruptive-spouted type lahar caused by the 2014 eruption was much smaller than other recorded syneruptive lahars, however, such as snowmelt type lahars or a crater lake breakout type lahar.

The mineral assemblage identified from samples of the syneruptive-spouted type lahar deposits is similar to that

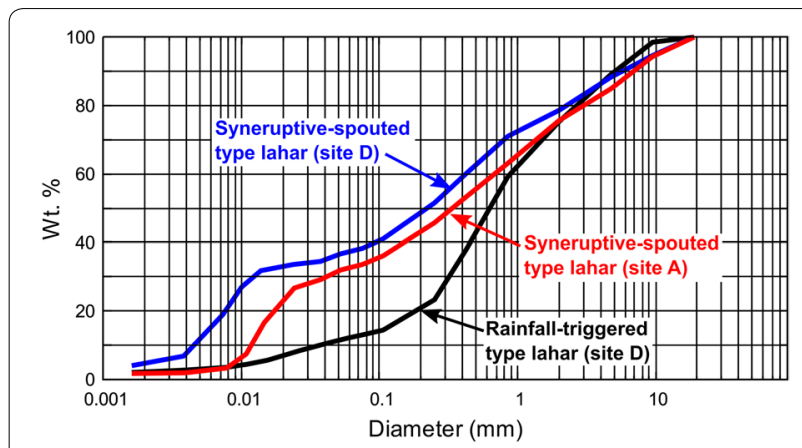

Fig. 6 Grain-size distribution analyses of the syneruptive-spouted type lahar deposits (sites A and D) and debris flow deposit (site D) of the ash-fall deposits from the same eruption (Minami et al. 2016). Minami et al. (2016) estimated that ash falls were derived mainly from shallow depths, within $2 \mathrm{~km}$ of
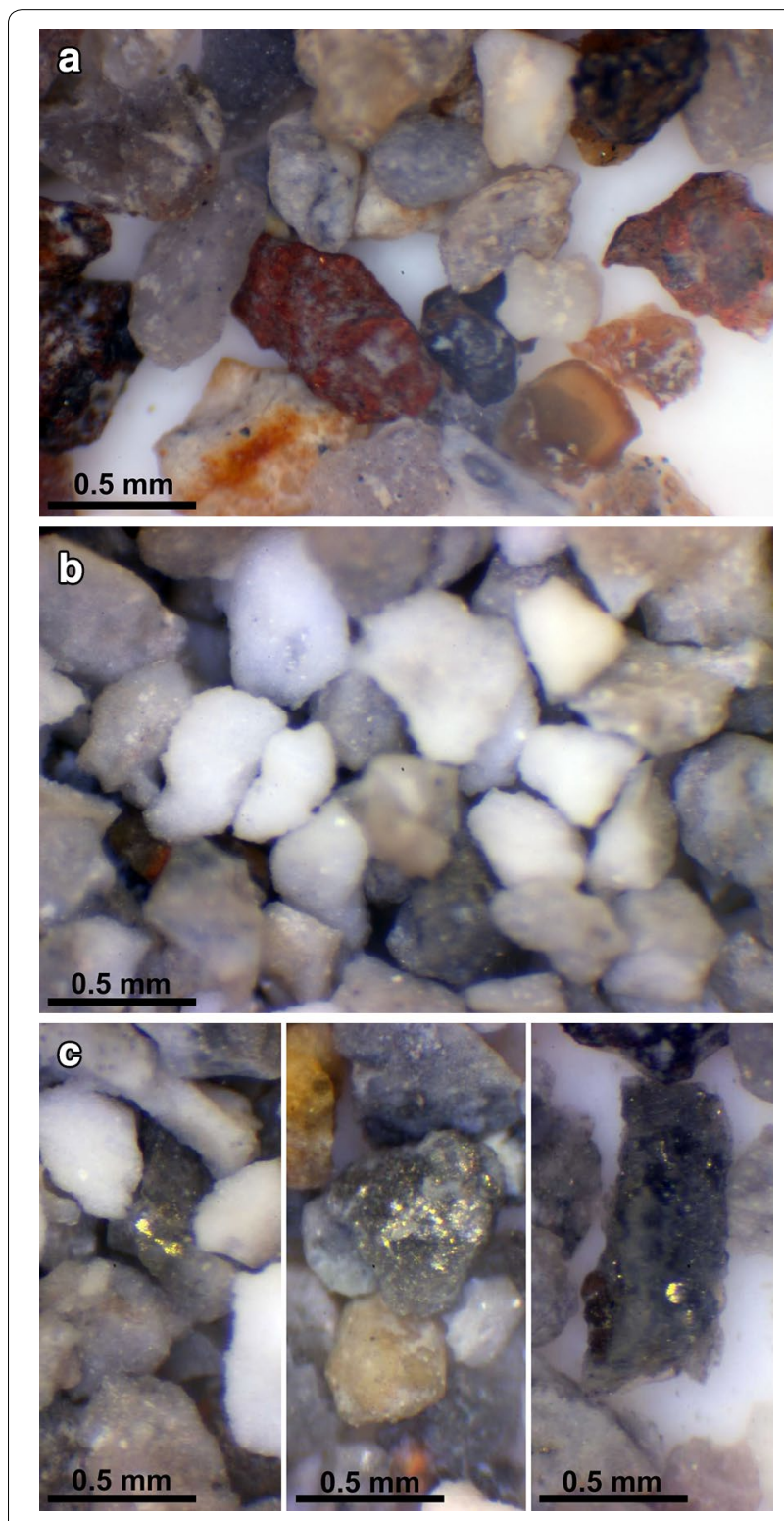

Fig. 7 Photomicrographs of deposits from site D: a debris flow deposit, b syneruptive-spouted type lahar deposit, and $\mathbf{c}$ pyrite only occurs in the syneruptive-spouted type lahar deposits 

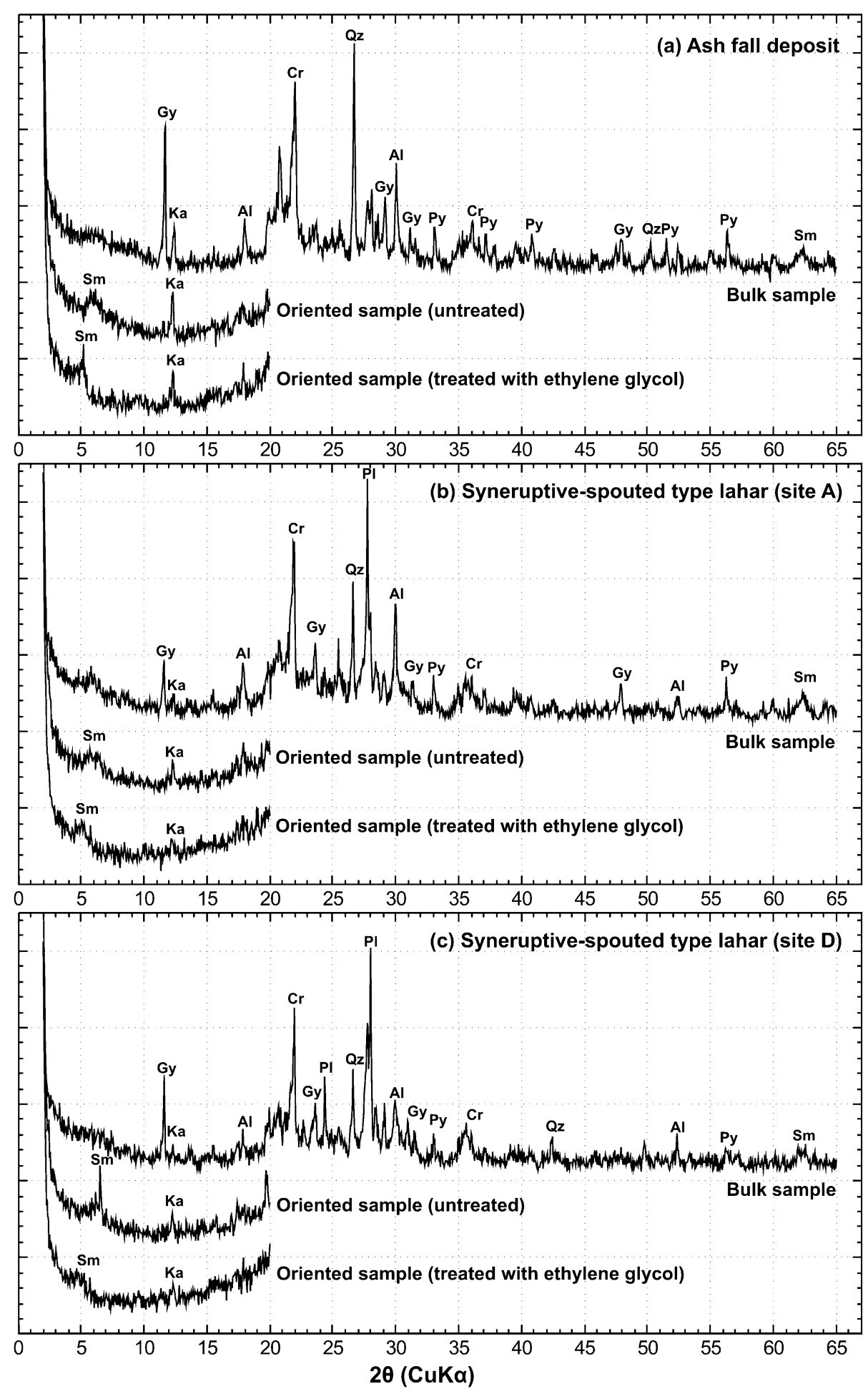

Fig. 8 X-ray diffraction chart of ash-fall and syneruptive-spouted type lahar deposits. Results for an untreated bulk sample and the $<2$ - $\mu$ m-diameter fraction sample after various treatments. XRD analysis was carried out using an XRD-6000 device (Shimadzu Corporation) with a Cu tube analytical setup and operating conditions of $30 \mathrm{kV}, 20 \mathrm{~mA}$, and a scanning speed of 2 degrees per minute 
Table 1 Mineral assemblages of the ash-fall and syneruptive-spouted type lahar deposits

\begin{tabular}{|c|c|c|c|c|c|c|c|c|}
\hline Sample & Qz & $\mathrm{PI}$ & $\mathrm{Cr}$ & Al & Gy & $\mathrm{Ka}$ & Sm & Py \\
\hline Ash-fall deposit & ++ & + & ++ & + & + & $\operatorname{tr}$ & $\operatorname{tr}$ & $\operatorname{tr}$ \\
\hline Syneruptive-spouted type lahar deposit (site A) & + & ++ & ++ & + & $\operatorname{tr}$ & $\operatorname{tr}$ & $\operatorname{tr}$ & $\operatorname{tr}$ \\
\hline Syneruptive-spouted type lahar deposit (site D) & + & ++ & ++ & $\operatorname{tr}$ & + & $\operatorname{tr}$ & $\operatorname{tr}$ & $\operatorname{tr}$ \\
\hline
\end{tabular}

Abbreviations of minerals $Q z$ quartz, PI plagioclase, $C r$ cristobalite, $A$ l alunite, Gy gypsum, Ka kaolinite, $S m$ smectite, $P y$ pyrite. $++>+>t r$ relative amounts of minerals

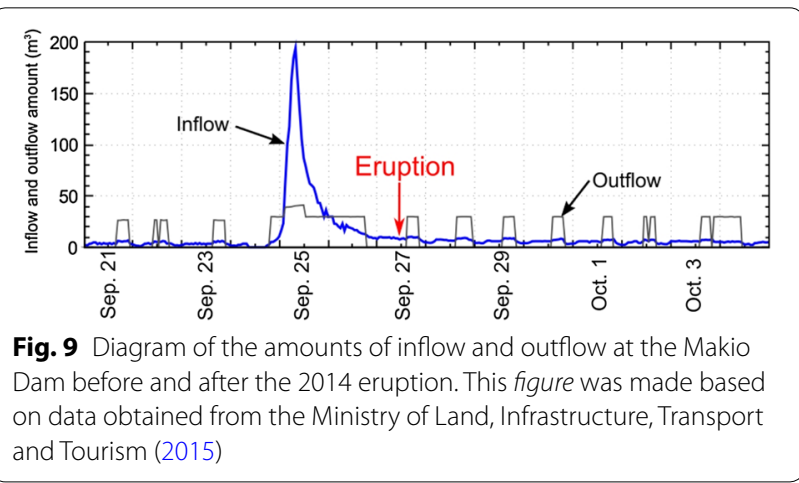

the surface. The syneruptive-spouted type lahar deposits are therefore inferred to also have originated from shallow depths.

We have reviewed representative syneruptive-spouted type lahars recorded in Japan (Table 2). Phreatic eruptions are not uncommon volcanic phenomena in Japan, although this type of lahar is extremely small in scale (e.g., the lahar associated with the 1992 eruption of Shinmoedake). The syneruptive-spouted type lahar attributed to the September 2014 eruption of Mount Ontake had the longest runout distance and largest volume of all cases evaluated for this study.

As of 2016, volcanic hazard maps for 42 of the 110 active volcanoes in Japan have been published by local governments; however, phreatic eruptions are noted as a potential hazard on only 22 of these maps. Furthermore, only three volcanoes (Meakandake, Hakone, and Garandake) have been noted as associated with syneruptive-spouted type lahars on these hazard maps. Predicting the occurrence of syneruptive-spouted type lahars alongside phreatic eruptions is challenging because the associated preeruptive phenomena, such as ground deformation and volcanic tremors, are very gentle and/ or small in scale. In addition, a syneruptive-spouted type lahar is a small-scale phenomenon that causes little direct damage to infrastructure, although it may have long-term influence on water quality. An increase in turbidity and a decrease in $\mathrm{pH}$ are expected to occur downstream of Nigorisawa at Mount Ontake after every heavy rainfall event for several years. Therefore, syneruptive-spouted

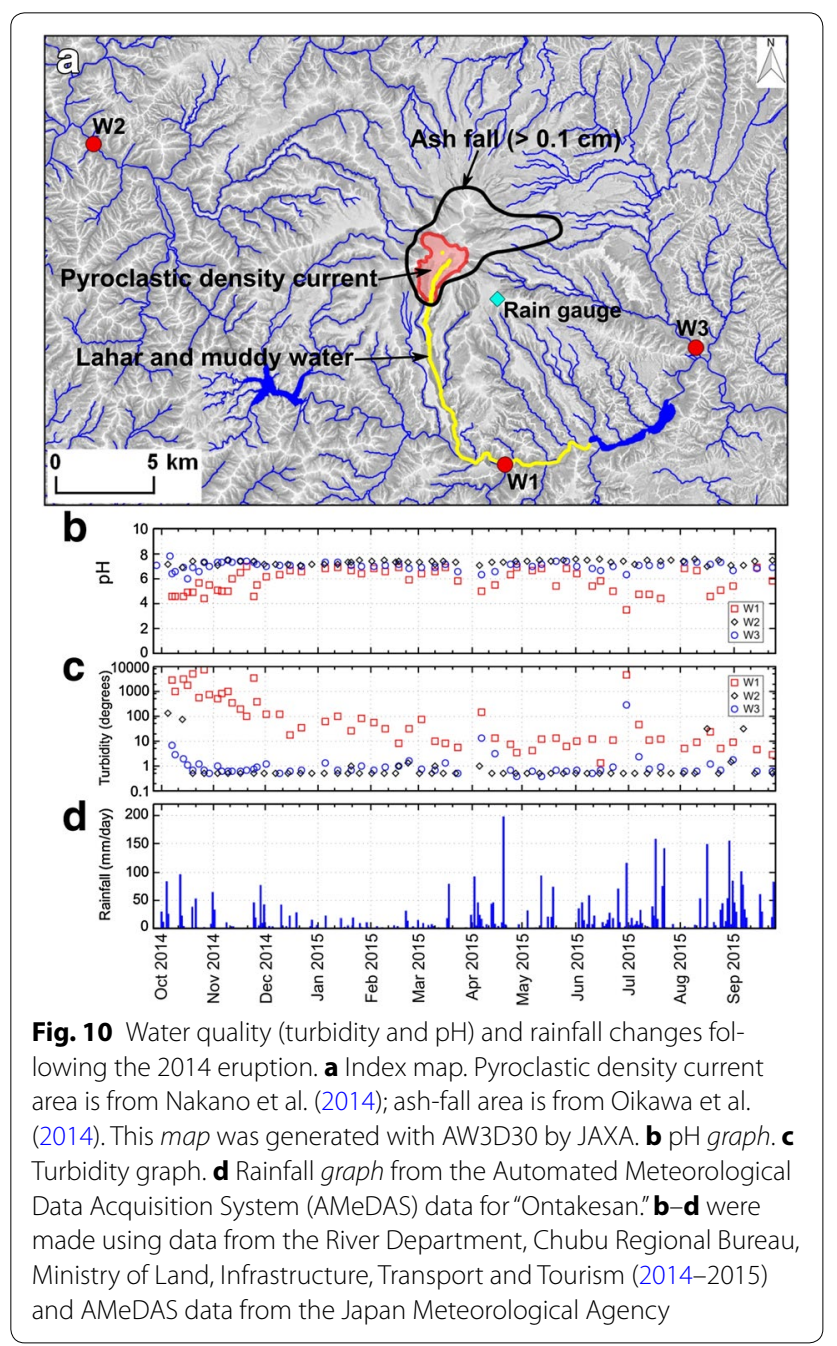

type lahars that could cause indirect, long-term damage should be considered in hazard mapping when volcanic disaster prevention measures are planned, as was done for the hazard map of the Iwaki Volcano after its 2014 eruption (Aomori Prefectural Government and Aomori Office of River and National Highway 2015). For other volcanoes, corrections should be made to their hazard maps to help create more effective hazard prevention plans. 
Table 2 Comparison of characteristics of syneruptive-spouted type lahars recorded in Japan

\begin{tabular}{llllll}
\hline Volcano & Year & Eruption type & Lahar volume $\left.\mathbf{~ ( m ) ~}^{\mathbf{3}}\right)$ & Distance travelled $\mathbf{( k m )}$ & Damage \\
\hline Yakedake & 1962 & Phreatic & $?$ & $2.5^{\mathrm{a}}$ & - \\
Niigata Yakeyama & 1974 & Phreatic & $1.0 \times 10^{5 \mathrm{~b}}$ & $>11^{\mathrm{b}}$ & - \\
Shinmoedake & 1992 & Phreatic & $4.0 \times 10^{\mathrm{c}}$ & $0.2^{\mathrm{d}}$ & - \\
Kuju & 1995 & Phreatomagmatic & $?$ & $0.2^{\mathrm{e}}$ & - \\
Akita Yakeyama & 1997 & Phreatic & $2.0 \times 10^{3 \mathrm{f}}$ & $0.1^{\mathrm{f}}$ & Destroyed buildings and bridges \\
Usuzan & 2000 & Phreatomagmatic & $1.0 \times 10^{5 \mathrm{~g}}$ & $0.8^{\mathrm{h}}$ & - \\
Meakandake & 2006 & Phreatic & $4.0 \times 10^{2 \mathrm{i}}$ & $1^{\mathrm{j}}$ & - \\
Ontake & 2014 & Phreatic & $1.2 \times 10^{5 \mathrm{k}}$ & $5^{\mathrm{k}}$ & \\
\hline
\end{tabular}

a Ossaka and Ozawa (1966)

b Chihara et al. (1977)

c ERI and KU (1992)

d Estimated from Fig. 7 in ERI and KU (1992)

${ }^{e}$ Hoshizumi et al. (1996)

fOhba et al. (2007)

${ }^{g}$ Mizugaki et al. (2001)

h Measured from Fig. 3 in Mizugaki et al. (2001)

i Yano et al. (2007)

j Sasaki et al. (2006)

k This study

\section{Authors' contributions}

HS carried out the aerial photointerpretation, field research, and hazard map review and drafted the manuscript. TC conducted field research and analysis of samples and helped draft the manuscript. HK carried out field research and the review of similar phenomena. SN performed the analysis of indirect impacts. All authors read and approved the final manuscript.

\section{Acknowledgements}

We thank Drs. W. Hirose and T. Kanamaru for their assistance in the preparation of this manuscript. We are grateful to the Kiso District Forest Office of the Chubu Regional Forest Office, Forestry Agency, for their assistance. We extend our appreciation to all staff members of Asia Air Survey Co., Ltd., for their assistance and support. This study was supported in part by the Research Subcommittee on Volcanic Engineering of the Geotechnical Engineering Committee, Japan Society of Civil Engineers.

\section{Competing interests}

The authors declare that they have no competing interests.

Received: 17 December 2015 Accepted: 28 July 2016

Published online: 09 August 2016

\section{References}

Aomori Prefectural Government, Aomori Office of River and National Highway (2015) Iwakisan volcano eruption emergency mitigation measures and erosion control plan. http://www.pref.aomori.lg.jp/soshiki/kendo/ kasensabo/files/H27.3iwakisangensaikeikaku1.pdf. Accessed 15 June 2016

Chiba T, Kaneta S, Suzuki Y (2008) Red Relief Image Map: new visualization method for three dimensional data. Int Arch Photogram Rem Sens Spatial Inform Sci 37:1071-1076

Chihara K, Suzuki M, Kobayashi K (1977) On the earth flow caused by the 1974 eruption of Yakeyama Volcano, Niigata Prefecture. Annual Report of the Research Laboratory of Ground Failure (the Jibansaigai-Ken). Fac Sci Niigata Univ 3:1-18 (in Japanese)
Earthquake Research Institute, The University of Tokyo (ERI), Kyoto University (KU) (1992) Volcanic Activity of Shinmoe-dake, Kirishima Volcanoes Part 2: March-May 1992. Rep Coord Comm Predict Volcan Erupt 53:81-93 (in Japanese)

Hayashi S, Kitahara O, Kusano S, Watari M, Nagai Y, Kunitomo M, Ishizuka T, Fujimura N (2015) Emergency survey and countermeasure for sediment disaster due to eruption of Mt. Ontake on September 2014. J Jpn Soc Eros Control Eng 67(6):86-91 (in Japanese)

Hirose W, Okazaki N, Ishimaru S, Tajika J (2007) Mudflow and its deposits occurred by the eruption on March 2006 at Meakandake volcano, Hokkaido, northern Japan. Rep Geol Surv Hokkaido 78:57-81 (in Japanese with English abstract)

Hoshizumi H, Kawanabe Y, Kamata H, Saito E (1996) Eruption and products of Kuju volcano on October, 1995. Chishitsu News 498:33-35 (in Japanese)

Kaneko T, Maeno F, Nakada S (2016) 2014 Mount Ontake eruption: characteristics of the phreatic eruption as inferred from aerial observations. Earth Planets Space 68:72. doi:10.1186/s40623-016-0452-y

Maeno F, Nakada S, Oikawa T, Yoshimoto M, Komori J, Ishizuka Y, Takeshita Y, Shimano T, Kaneko T, Nagai M (2016) Reconstruction of a phreatic eruption on 27 September 2014 at Ontake volcano, central Japan, based on proximal pyroclastic density current and fallout deposits. Earth Planets Space 68:82. doi:10.1186/s40623-016-0449-6

Mannen K, Doke R, Harada M, Honda R, Idadera K, Kikugawa G, Yukutake Y, Takenaka J (2015) Chronology of the 2015 eruption of Hakone volcano, Japan. Abstracts of the Volcanological Society of Japan 2015 Fall Meeting, 40-40 (in Japanese)

Minami Y, Imura T, Hayashi S, Ohba T (2016) Mineralogical study on volcanic ash of the eruption on September 27, 2014 at Ontake volcano, central Japan: correlation with porphyry copper systems. Earth Planets Space 68:67. doi:10.1186/s40623-016-0440-2

Ministry of Land, Infrastructure, Transport and Tourism (2015) Water information system. http://www1 river.go.jp/. Accessed 15 June 2016

Mizugaki S, Mishima Y, Kikuchi S (2001) The sediment disasters and mudflows by the 2000 Eruption of Usu Volcano. J Jpn Soc Eros Control Eng 54(3):47-53 (in Japanese with English abstract)

Nakano S, Oikawa T, Yamasaki S (2014) Eruption of Ontakesan in September, 2014. GSJ Chishitsu News 3:289-292 (in Japanese) 
Ohba T, Taniguchi H, Miyamoto T, Hayashi S, Hasenaka T (2007) Mud plumbing system of an isolated phreatic eruption at Akita Yakeyama volcano, northern Honshu, Japan. JVolcanol Geotherm Res 161(1-2):35-46. doi:10.1016/j.jvolgeores.2006.11.001

Oikawa T, Chiba T, Suzuki Y (2014) Eruption history and 2014 eruption of Ontake volcano. Kagaku 84:1218-1225 (in Japanese)

Ossaka J, Ozawa T (1966) The 1962-ejecta from Mt. Yake, Nagano-Gifu Prefectures, and its Mechanism of Eruption. Bull Volcanol Soc Jpn 11:17-29 (in Japanese with English abstract)

River Department, Chubu Regional Bureau, Ministry of Land, Infrastructure, Transport and Tourism (2014-2015) About the quality of the water monitoring by ash falls with the Mount Ontake eruption, http://www. cbr.mlit.go.jp/saigai/NEWS/MAIN/140927ontakefunka/02higai/higai.htm. Accessed 15 June 2016
Sasaki H, Mukoyama S, Inaba C (2006) The Eruption of Meakandake Volcano on March 21, 2006, Hokkaido, Japan. Bull Volcanol Soc Jpn 51:347-350 (in Japanese)

Vallance JW, Iverson RM (2015) Lahars and their deposits. In: Sigurdsson H, Houghton B, Rymer H, Stix J, McNutt S (eds) The encyclopedia of volcanoes, 2nd edn, pp 649-664

Yano M, Inaba C, Sasaki H, Miyata N, Goshima Y (2007) Mudflow of the eruption of Meakandake Volcano on March, 2006. Jpn Soc Erosion Control Eng 62:110-111 (in Japanese)

\section{Submit your manuscript to a SpringerOpen ${ }^{\circ}$ journal and benefit from:}

- Convenient online submission

- Rigorous peer review

Immediate publication on acceptance

- Open access: articles freely available online

- High visibility within the field

- Retaining the copyright to your article 